\title{
A Study on Assessment of Project Management through PMO
}

\author{
Akshay Khandave ${ }^{1}$, Dr. M R Nagare ${ }^{2}$ \\ ${ }^{1}$ PG student, Veermata Jijabai Technological Institute Mumbai, India,400019 \\ ${ }^{2}$ Asso. Professor, Veermata Jijabai Technological Institute Mumbai, India, 400019
}

\begin{abstract}
Project Management Office (PMO) is a significant and far-reaching marvel of hierarchical task the executives in the cutting edge world. Be that as it may, numerous questions stay about its role, implementation, significance and value for the host organization. The given study had a purpose to investigate if and how can PMO bring and sustain value, highlighting the specifics of the engineering customer services companies. The sub-inquiries of the investigation are viewed as the explanations behind PMO foundation, and its ideal execution and obligations. Primary work streams are investigated in this study with describing monitoring of agile projects with different metrics. The picked methodology permitted to gather broad information contemplating of PMO and its business value and project environment. In the survey conducted for this study about 95 responses across various industries and working professionals and also agile reports are stated with the study of existing real time challenges of resources and project implementation and its management to deliver right deliverables to client/end user. Existing PMOs and PMO-like drives just as current difficulties of task the executives were inspected, and expected worth of undertaking the board was recognized. Basing on the organizational context and recommendations from the literature, suggestions were made for each model of PMO regarding frameworks of $P M O$ implementation and functional responsibilities. Common for all the three cases, project-related competence development and cross-project learning were found to be a potential area of PMO responsibilities.
\end{abstract}

Keywords- Project management office; PMO; value of project management; PMO implementation; PMO responsibilities; customer services organization, agile reports.

\section{I - INTRODUCTION}

$\mathbf{P}$ roject in a business environment is a finite piece of work, undertaken within defined cost and time constraints and directed at achieving a stated business benefit" (Buttrick, 2005). Moreover, technical organizations are increasingly becoming project based. The operational activities within present-day organizations are being split onto program of project aligned to achieve the organization's strategy. This presents the growing importance of managing program(s), which indirectly involve managing the portfolio of projects. Organizations invest significant resources in their projects to meet the business objectives. However, a KPMG survey (2007) reports that despite the significant resources invested in projects, companies still lose millions of capitals each year through poor project performance and jeopardize their reputation as a result of significant project failure. The report also suggests that the majority of organizations, who experienced a project failure, could not determine the magnitude of this failure. These findings emphasize the need for organizations to focus on consistent 


\section{International Journal of Innovations in Engineering and Science, www.ijies.net}

project/program management success and on greater transparency in project reporting \& governance.

In response to this growing demand in project and program management success, many organizations are establishing a central unit, which manages organizational project knowledge and possesses expertise related to project \& program management practices, techniques, and standards (Latavec, 2006). These centers are referred to in many ways such as program management office (PMO), Project management office or project office. Irrespective of the reference term, these centers serve important functions within a project-oriented environment. This research explores various models, roles and functions of this central Programme management office; investigates its role in aligning project activities with business strategies;and evaluates its impact on project performance.

\section{II - LITERATURE REVIEW}

Professor Young H. Kwak concluded for his work that his research will represent an effort to make substantial inclusions to the inadequate knowledge of PMO in the project management community. It is planned to provide invaluable information for those operating, expanding or considering PMO in its advanced project management practice. By demonstrating the relationship between PMO effectiveness and project success, scholars and practitioner will have a better knowledge and confidence adapting PMO in the ever-increasing project driven business world.

Simon P Philbin, the director of Program Management from Imperial College London stated in his study that ultimately the main purpose of the PMO is to facilitate project success through standardizing projects and implementing best practice, mitigating project risks and supporting effective project delivery according to schedule, budget and scope requirements. Although the PMO has been adopted by many organizations there are unfortunately still a lack of studies in the literature as well as supporting frameworks that describe the functioning of the PMO. Consequently, his paper has provided the results from an exploratory study in order to investigate the role, structure and processes of the PMO.

Eric John Darling, a faculty from University of Southern Queensland, Australia, explained a different approach in his study. Furthermore, he elucidated how functions and practices expected of the PMO differ as widely as industries and organizations, which host them. In his finding he stated about his research reveling how the form and use of structure we call PMO have evolved and adopted over time.

Kashumi Madampe in his research work of adopting agile project management for software development industry stated much efficiently that stakeholders are getting benefited from agile project management. She Justified for many literatures for supporting agile project management and also aimed her work in identifying how successful project management can be achieved through agile methods. She concluded that despite of having many agile methods scrum and extreme programming is widely used for better results.

\section{III - METHODOLOGY}

Methodology used to this study was quantitative approach and survey amongst several intellects across various industries and job profiles. Qualitative data is again re-structured in quantitative analysis illustrated in charts. The data and survey contain PMO frameworks and its primary work streams.

\section{IV - DATA GATHERING AND ANALYSIS}

Project and Program Management:

It is referred to 'projects, as building blocks in the design and execution of organizational strategies, with the means for bringing about realizable changes in product and processes. Similarly, the project management institute (PMBOK,6th edition) defines a project as a 'temporary endeavor to create a unique product, services, or result'. Projects have constraints such as 'scope, time and cost' in which project 'quality' is ultimately affected by the balance between these three elements. In order to meet these constraints and to accomplish project successfully. PMI (PMBOK, 6th Edition) affirms that the process of project management by undertaking multiple stages such as project initiation, planning, execution, control and closure.

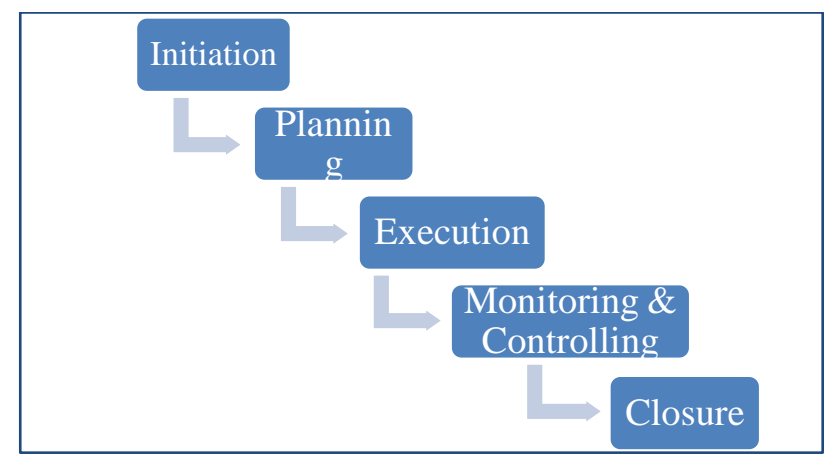

Fig 1-Phases of Project 


\section{International Journal of Innovations in Engineering and Science, www.ijies.net}

Most of the definitions of the term 'Program Management' refer to the coordinated management of a collection of interrelated projects. PMI (PMBOK, 2008) defines program management "as a centralized, coordinated management of a group of projects to achieve the program's strategic objectives and benefits". Through the program management, organizations can be able to achieve strategic benefits that cannot be reached through managing projects individually.

The contraction PMO can be used for three altered types of offices within an organization:

- Project Management Office

- Program Management Office

- Portfolio Management Office

\section{PMO:}

The PMI (PMBOK, 6th Edition) defines a Project Management Office (PMO) as "an organizational unit to centralize and coordinate the management of projects under its domain. PMO oversees the management of projects, programs or a combination of both". This centralized office facilitates the management of projects or programs which can utilize the sharing of resources, methodologies, tools and techniques and focus on the high-level project management activities. However, this definition illustrates the PMO as an administrative function and hence its suggests the role of PMO as strategic function in coordinating, prioritizing, planning, overseeing and monitoring projects to achieve business objectives and benefits. PMO operates at different levels in organizations. A PMO can be for a particular project or program, for department such as human resources or information technology, or it can be at the organizational level. In large organizations, there can be multiple PMOs at different level.

Project Failure (A review of case study):

According to Standish survey report on the triple constraints of being on time, within the budget and functionality delivered on average. Below figure shows graphical representation of Standish survey results.

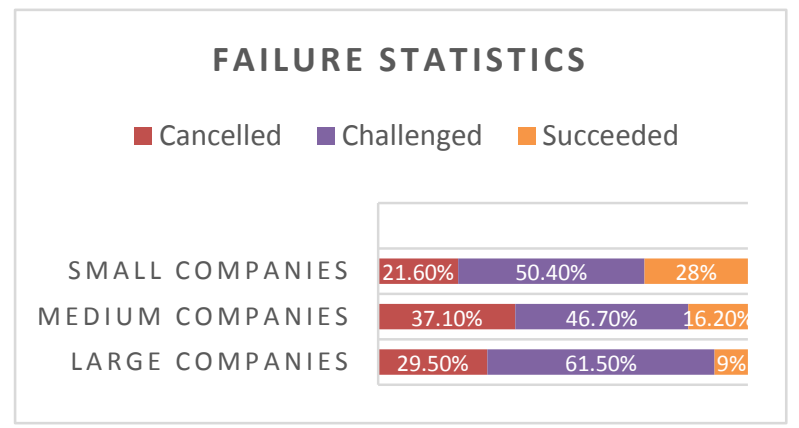

Fig 2- Project Failure Statistics
Table 1: Project Category and Success Rate

\begin{tabular}{|l|l|l|}
\hline Category & Description & Results \\
\hline Success & $\begin{array}{l}\text { The project is completed on } \\
\text { time and in budget, with all } \\
\text { functions and features initially } \\
\text { specified }\end{array}$ & \\
\hline Challenged & $\begin{array}{l}\text { The project is completed and } \\
\text { operational but over budget, } \\
\text { over the time estimate, and } \\
\text { offers fewer features and } \\
\text { functions than originally } \\
\text { specified. }\end{array}$ & \\
\hline Cancelled & $\begin{array}{l}\text { The project is cancelled at } \\
\text { some point during the } \\
\text { development cycle }\end{array}$ & $29 \%$ \\
\hline
\end{tabular}

The reasons of project failure can be listed as below:

- Organizations are inconsistent in managing and reporting on projects

- People waste a lot of time in finding out how to get the things done and often find them they are reinventing the wheel

- Documented processes are only on paper and often not followed

- Too much bureaucracy creates a lot of bottlenecks and slows down delivery

- No mechanism to improve business processes

- No structural governance or checkpoints for projects

- Few opportunities to share information, ideas best practices and lessons learned

The purpose of PMO:

Several literature sources discuss the objectives and reasons behind the establishment of PMO.

Some of the motivations for setting up a PMO can be listed as follows: improving all elements of project management and achieving a common project management approach (through standards and methodologies); more efficient use of human and other resources in a multiple project environment; and improving quality and customer satisfaction.

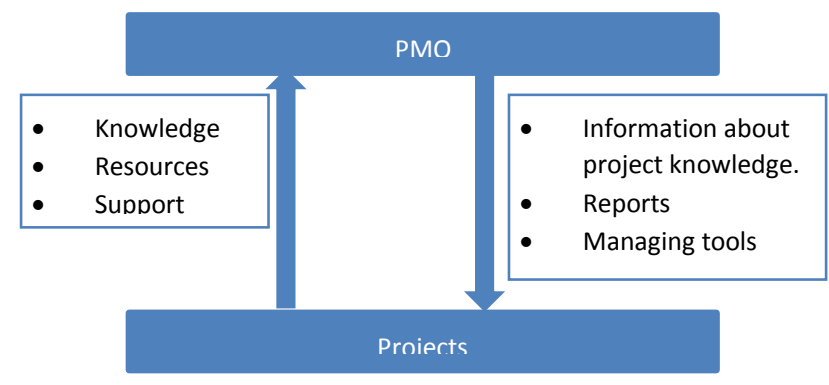

Fig 3-Relationship between project and PMO 


\section{International Journal of Innovations in Engineering and Science, www.ijies.net}

PMO can establish a strong link between organizational strategy and the activities at the project level. From an operational perspective strategy formulation is carried out by senior management and inputs are provided from the project level such as project progress, workload/resources capacity, new development opportunities. Organizations that employ project management as their strategic consistency produce better performance, more accurate cost and schedule forecasts, and early problem recognition. Subsequently, this strategic in turn provides the firm a competitive advantage.

PMO structure and Models:

PMO structures and models are backbone of office. There are mainly five PMO frameworks defined at organizational level, these can be listed as below:

1. Divisional PMO: Divisional PMO provides projectrelated services to support a business unit or division within an organization including, but not limited to, portfolio management, governance, operational project support and human resources utilization.

2. Project-specific PMO: Project Office provides project-related services as a temporary entity established to support a specific project or program. May include supporting data management, coordination of governance and reporting, and administrative activities to support the project or program team.

3. Project control office: Provides enabling processes to continuously support management of project, program or portfolio work throughout the organization. Uses the governance, processes, practices, and tools established by the organization and provides administrative support for delivery of the project, program or portfolio work within its domain.

4. Global PMO: The highest-level PMO in organizations having one, this PMO is often responsible for alignment of project and program work to corporate strategy, establishing and ensuring appropriate enterprise governance, and performing portfolio management functions to ensure strategy alignment and benefits realization.

5. Center of Excellence: Center of excellence supports project work by equipping the organization with methodologies, standards and tools to enable project managers to better deliver projects. Increases the capability of the organization through good practices and a central point of contact for project managers.

Primary workstreams of PMO:

The main work domains i.e., things PMO usually do can be listed as follows. Each domain has PMO's primary and secondary workstreams, these can be listed as below:

1. Standard, methodology and processes: Define methodology and metrics used in project management, developing and improving processes for better efficiency of project resources, set standards for operations.

2. Project/program delivery management: Define business goals, resource management, schedule, scope and cost management, business value management, risk management, stakeholder management, communication and integration management.

3. Portfolio management: Prioritization on the basis of business value generation, strategic alignment, portfolio reporting, resource management and allocations, opportunities and investment analysis, risk management, business value generation tracking and reporting.

4. Talent management: Tracking career paths and career development, skill development, handling certifications, qualifications and credentials.

5. Governance and performance management: Performance reporting and issue escalation, information distribution, managing metrics, KPIs and compliances, financial management.

6. Organizational change management: Customer and stakeholder satisfaction, project readiness assessment, stakeholder management and communication.

7. Administration and support: Providing, implementing and supporting tools, consulting, IT support.

8. Knowledge management: Define knowledge management policies, managing intellectual property, lessons learned and content management.

9. Strategic planning: Confirming strategic priorities, defining and aligning business goals, environmental scanning and opportunity analysis.

Analysis of PMO frameworks and workstreams:

From the survey conducted across various industries and professionals regarding what could be primary functions related to respective framework: 


\section{International Journal of Innovations in Engineering and Science, www.ijies.net}

Table 2- Primary functions of PMO

\begin{tabular}{|l|r|r|r|r|r|}
\hline Primary Functions Performed & $\begin{array}{l}\text { Divisional } \\
\text { PMO }\end{array}$ & $\begin{array}{l}\text { Project- } \\
\text { Specific } \\
\text { PMO }\end{array}$ & $\begin{array}{l}\text { Project } \\
\text { Controls } \\
\text { Office }\end{array}$ & $\begin{array}{l}\text { Global } \\
\text { PMO }\end{array}$ & $\begin{array}{l}\text { Center of } \\
\text { Excellence }\end{array}$ \\
\hline 1. Project/Program Delivery Management & \multicolumn{5}{|l|}{} \\
\hline a. Schedule/cost/scope management & $70 \%$ & $89 \%$ & $75 \%$ & $78 \%$ & $50 \%$ \\
\hline b. Communications & $68 \%$ & $77 \%$ & $76 \%$ & $75 \%$ & $48 \%$ \\
\hline c. Resource Management & $63 \%$ & $77 \%$ & $69 \%$ & $68 \%$ & $47 \%$ \\
\hline d. Project Integration & $55 \%$ & $73 \%$ & $61 \%$ & $63 \%$ & $41 \%$ \\
\hline e. Risk Management & $40 \%$ & $70 \%$ & $42 \%$ & $50 \%$ & $39 \%$ \\
\hline 2. Standards, Methodologies, Processes & \multicolumn{5}{|l|}{} \\
\hline a. Methology definition & $75 \%$ & $68 \%$ & $70 \%$ & $85 \%$ & $70 \%$ \\
\hline b. Process development and improvement & $69 \%$ & $63 \%$ & $68 \%$ & $75 \%$ & $80 \%$ \\
\hline c. Metrics definition & $53 \%$ & $48 \%$ & $42 \%$ & $62 \%$ & $55 \%$ \\
\hline 3. Portfolio Management Prioritization & \multicolumn{5}{|l|}{5} \\
\hline a. Portfolio reporting & $69 \%$ & $76 \%$ & $56 \%$ & $78 \%$ & $55 \%$ \\
\hline b. Prioritization & $55 \%$ & $63 \%$ & $47 \%$ & $68 \%$ & $59 \%$ \\
\hline c. Resource management allocation & $47 \%$ & $61 \%$ & $40 \%$ & $64 \%$ & $45 \%$ \\
\hline
\end{tabular}

\begin{tabular}{|c|c|c|c|c|c|}
\hline PMO Evaluation & $\begin{array}{l}\text { Divisio } \\
\text { nal } \\
\text { PMO }\end{array}$ & $\begin{array}{l}\text { Project- } \\
\text { Specific } \\
\text { PMO }\end{array}$ & $\begin{array}{l}\text { Project } \\
\text { Controls } \\
\text { Office } \\
\end{array}$ & $\begin{array}{l}\text { Global } \\
\text { PMO }\end{array}$ & $\begin{array}{l}\text { Center of } \\
\text { Excellence }\end{array}$ \\
\hline \multicolumn{6}{|c|}{$\begin{array}{l}\text { Criteria that the PMO is evaluated on (this is } \\
\text { things based. on which performace of PMO and } \\
\text { value of PMO is assessed) }\end{array}$} \\
\hline a. Project delivery vs. schedule evaluations & $77 \%$ & $70 \%$ & $78 \%$ & $78 \%$ & $69 \%$ \\
\hline b. Customer feedback evalutions & $70 \%$ & $68 \%$ & $67 \%$ & $69 \%$ & $70 \%$ \\
\hline c. Project cost vs. budget evaluatios & $66 \%$ & $67 \%$ & $66 \%$ & $65 \%$ & $72 \%$ \\
\hline d. Formal evaluations of project managers & $58 \%$ & $62 \%$ & $51 \%$ & $58 \%$ & $56 \%$ \\
\hline e. Feedback of PMO staff & $55 \%$ & $57 \%$ & $42 \%$ & $52 \%$ & $57 \%$ \\
\hline \multicolumn{6}{|l|}{ Primary focus/industry of PMO } \\
\hline Information Technology & $15 \%$ & $25 \%$ & $29 \%$ & $35 \%$ & $12 \%$ \\
\hline Consulting & $12 \%$ & $13 \%$ & $19 \%$ & $22 \%$ & $28 \%$ \\
\hline Financial services & $11 \%$ & $15 \%$ & $17 \%$ & $19 \%$ & $19 \%$ \\
\hline Manufacturing/automobile industry & $8 \%$ & $10 \%$ & $13 \%$ & $14 \%$ & $12 \%$ \\
\hline E-commerce & $9 \%$ & $14 \%$ & $16 \%$ & $21 \%$ & $18 \%$ \\
\hline Logistics industry & $12 \%$ & $16 \%$ & $21 \%$ & $25 \%$ & $14 \%$ \\
\hline
\end{tabular}

\section{V - CONCLUSION}

As gone through various literatures and survey, it is evident that for the current organization framework of Global PMO is most suitable since it will govern operations in different business units at high level. There cannot be rigid structure for PMO to implement in organization and it has to be customized according to need to organization and roles and responsibilities varies are office gets matured.
Following challenges are observed for PMO:

- Rigid corporate culture and failure to manage organizational resistance to change

- Lack of appropriate change management strategy

- Failure to design a PMO around a company's specific needs

- Lack of stakeholder commitment to common methodology and tools for the PMO

- Poor definition and communication of PMO goals and purpose 


\section{International Journal of Innovations in Engineering and Science, www.ijies.net}

- Lack of full support of the senior management and various stakeholders to the PMO

- Lack of defined scope and size of PMO implementation

- Lack of training and communication on PMO implementation to all stakeholders

From the project management value framework, following are the elements when framework is found relevant:

- Improve project performance (save costs, shorten

duration, improve quality, realize commercial goals)

- Improve the competencies of the enterprise (enhance project management capability in projects and project portfolio management, enhance knowledge management, improve technology innovation, smooth organization transformation)

- Increase revenue (increase the project income, broaden the business opportunities)

- Cultivate the personnel (clearer career path, better motivation and training)

- Improve customer relationship management (better customer communication, greater customer satisfaction, stronger customer loyalty, attract new customers)

\section{REFERENCES}

[1] Monique Aubry, Brian Hobbs, Denis Thuillier: A new framework for understanding organizational project management through the PMO, International Journal of Project Management 25 (2007) 328-336.Everett, H.R. (1995). Sensors for Mobile Robots: Theory and Application. A K Peters, Ltd, MA, USA.

[2] Simon P Philbin, EXPLORING THE PROJECT MANAGEMENT OFFICE (PMO) - ROLE, STRUCTURE AND PROCESSES, Proceedings of the American Society for Engineering Management 2016 International Annual Conference S. Long, E-H. Ng, C. Downing, \& B. Nepal eds.

[3] S. Chandramouli, Dr. G. Rajesh Kumar, HR MANAGEMENT BEST PRACTICES IN IT ORGANIZATIONS WITH SPECIAL REFERENCE TO AGILE - SCRUM PROJECTS, International Journal of Human Resource \& Industrial Research, Vol.3, Issue 2, Feb-Mar, 2016, pp 16-26 ISSN: 2349 -3593 (Online), ISSN: $2349-4816$ (Print)

[4] Seweryn Spalek, Improving Industrial Engineering Performance through a Successful Project Management Office, Inzinerine EkonomikaEngineering Economics, 2013, 24(2), 88-98.

[5] Kashumi Madampe, Successful Adoption of Agile Project Management in Software Development Industry, International Journal of Computer Science and Information Technology Research ISSN 2348120X (online) Vol. 5, Issue 4, pp: (27-33), Month: October - December 2017

[6] Shai Rozenes, Gad Vitner, The training methodology of project management office (PMO) personnel, Industrial And Commercial Training $J$ Vol. 41 No. 1 2009, pp. 36-42, Q Emerald Group Publishing Limited, ISSN 0019-7858

[7] Chris VanHoeck, Why PMO fail and how ensure their success, ISG (Information Services Group) www.isg-one.com. 